\title{
Pengembangan Model Persediaan Economic Order Quantity dengan Mempertimbangkan Faktor Kedaluwarsa, Kelonggaran Waktu Pembayaran, dan Potongan Harga
}

\author{
Candy Wirawan ${ }^{1}$, Roland Y. H. Silitonga ${ }^{2 *}$ \\ ${ }^{1,2}$ Program Studi Teknik Industri, Institut Teknologi Harapan Bangsa, Bandung, Indonesia \\ ( ${ }^{*}$ roland@ithb.ac.id)
}

\begin{abstract}
Abstrak - Model persediaan deterministik digunakan untuk mencari solusi optimal di mana besar permintaannya diketahui pasti dan tidak memiliki variansi. Perusahaan yang memproduksi makanan untuk dijual, memiliki tiga hal yang harus diperhatikan dalam mengendalikan persediaannya. Ketiga hal itu adalah bahan makanan yang dapat kedaluwarsa, kemungkinan untuk membayar dalam suatu tenggang waktu, serta kemungkinan untuk mendapatkan potongan harga jika membeli bahan makanan dalam jumlah besar. Tujuan dari penelitian ini adalah mengembangkan model deterministik dengan memperhatikan ketiga faktor tersebut. Model tersebut dibangun dengan kondisi satu jenis produk (single item). Pada penelitian ini, dilakukan pengembangan model beserta prosedur penggunaannya. Model ini untuk kemudian divalidasi dengan cara verifikasi dan uji coba model tersebut. Verifikasi model dilakukan dengan memeriksa konsistensi satuan di sisi kiri dan kanan tiap model. Uji coba model dilakukan dengan menggunakan data sekunder penelitian sebelumnya. Hasil verifikasi model menunjukkan bahwa model konsisten secara satuan. Hasil uji coba model menunjukkan bahwa prosedur yang dikembangkan dapat menentukan skenario yang valid, dan model dapat menghasilkan komponen biaya persediaan dan biaya persediaan total. Pengamatan terhadap jumlah produk yang rusak dan terkena denda pada tiap tingkatan harga juga menunjukkan hasil yang konsisten.
\end{abstract}

Kata kunci: all unit discount; economic order quantity; kedaluwarsa; kelonggaran waktu pembayaran

\section{PENDAHULUAN}

Sistem pengendalian persediaan yang baik akan membuat perusahaan dapat mengelola biaya dengan tetap memenuhi keinginan pelanggan, sehingga mendapatkan keuntungan, dan mampu bersaing di pasar. Persediaan yang dikelola dengan baik akan menekan biaya dengan tetap memastikan pemenuhan permintaan (Limanjaya \& Silitonga, 2018). Oleh karena itu, kebijakan perusahaan dibutuhkan untuk menentukan jumlah pemesanan optimal dan waktu pemesanannya.

Perusahaan yang memproduksi makanan untuk dijual, perusahaan kue misalnya, memiliki tiga hal yang harus diperhatikan dalam mengendalikan persediaannya. Ketiga hal itu adalah bahan makanan dapat kedaluwarsa, kemungkinan untuk membayar dalam suatu tenggang waktu setelah barang diterima, yang juga sering disebut kelonggaran waktu pembayaran, serta kemungkinan untuk mendapatkan potongan harga jika membeli bahan makanan dalam jumlah besar. Batas kedaluwarsa memberikan arti bahwa setiap produk yang diterima memiliki batas umur pakai. Terkait dengan persoalan kedaluwarsa, Pemerintah telah mengatur Undang-Undang No. 8 Tahun 1999 bahwa pelaku usaha dilarang memperdagangkan barang yang rusak atau kondisi yang tidak sesuai dengan mutu seharusnya kepada konsumen. Dalam hal ini dapat dikatakan bahwa produk yang sudah rusak tidak akan memiliki nilai jual lagi. Dalam pengadaan barang tentunya perusahaan juga berusaha mencari pemasok yang dapat memberikan kebijakan pembayaran secara kredit. Sunendar (2019) menyatakan bahwa pemasok dapat memberikan kelonggaran waktu pembayaran sebelum perusahaan membayar nilai pembelian sepenuhnya. Kelonggaran waktu pembayaran yang dimaksud adalah pemberian tambahan waktu setelah barang diterima sebelum pelanggan diwajibkan membayar. Hal ini berarti pelanggan dapat terlebih dahulu mendapatkan hasil dari penjualan produk yang dihasilkan dan menggunakan hasil penjualan tersebut untuk membayar, atau dengan kata lain, pemasok memberikan pinjaman modal. Umumnya tidak terdapat biaya tambahan selama pelanggan dapat membayar dalam jangka waktu yang diberikan, namun akan ada biaya tambahan ataupun bunga, jika pelanggan membayar melebihi batas waktu tersebut.

Selain kelonggaran waktu pembayaran, pemasok dapat juga memberikan potongan harga, jika melakukan pembelian dalam jumlah besar, sehingga diharapkan bahwa perusahaan akan membeli dalam jumlah besar. Potongan harga dapat dianggap mengurangi biaya persediaan total, yang dapat dibagi menjadi dua kelompok, yaitu potongan harga secara keseluruhan barang (all unit discount) dan potongan harga secara bertahap (incremental discount). Tujuan penelitian ini adalah mengembangkan model persediaan dengan 
memperhatikan masalah kedaluwarsa, kelonggaran waktu pembayaran, serta faktor potongan harga all unit discount, untuk mengakomodasi situasi nyata pada perusahaan makanan.

\section{STUDI LITERATUR}

Menurut Bahagia (2006) persediaan adalah sumber daya yang menganggur yang keberadaannya menunggu proses lebih lanjut. Adanya persediaan yang tinggi dapat mengakibatkan pemborosan yang meningkatkan biaya keseluruhan. Oleh karena itu, persediaan harus diminimalkan dengan tetap memenuhi permintaan dan menghindari terjadinya kekurangan persediaan. Biaya persediaan adalah semua pengeluaran atau kerugian yang ditimbulkan dari adanya persediaan selama horison waktu perencanaan tertentu. Biaya persediaan terdiri dari lima komponen, yaitu biaya pembelian, biaya pengadaan, biaya penyimpanan, biaya kekurangan, dan biaya sistemik.

Model persediaan dikembangkan untuk menjawab permasalahan kuantitatif yang muncul dalam sistem persediaan. Tujuannya adalah mendapatkan solusi optimal, yaitu penentuan ukuran lot pemesanan ekonomis, saat kapan pemesanan dilakukan, dan cadangan pengaman yang diperlukan. Model persediaan yang umum dipakai adalah model persediaan deterministik, model persediaan probabilistik, dan model persediaan tak tentu. Model persediaan deterministik sering digunakan untuk mencari solusi optimal di mana besar permintaannya diketahui pasti dan tidak memiliki variansi, atau variansinya diabaikan. Hal utama dalam model persediaan deterministik adalah menentukan besarnya stok operasi dengan menjawab dua pertanyaan, yaitu berapa jumlah yang harus dipesan untuk setiap kali pemesanan dan kapan pemesanan dilakukan, Model deterministik statis digunakan ketika besarnya permintaan dianggap sama (konstan) pada setiap periode (Bahagia, 2006). Model yang umum digunakan dalam permasalahan persediaan deterministik statis adalah Model Wilson yang sering disebut sebagai model EOQ (Economic Order Quantity). Dalam model deterministik statis tidak ada permasalahan yang berkaitan dengan cadangan pengaman (safety stock) karena tidak terjadi ketidakpastian baik dari sisi pemasok barang maupun dari sisi pemakai barang.

Model-model persediaan deterministik umumnya cocok untuk jenis produk yang memiliki variansi relatif kecil, sehingga rata-rata persediaan dapat digunakan sebagai parameter yang dianggap konstan (Silitonga \& Moses, 2021). Terdapat beberapa penelitian deterministik yang sudah mempertimbangkan faktor kedaluwarsa produk, kelonggaran waktu, dan all unit discount. Limansyah (2011) mengembangkan persediaan EOQ dengan mempertimbangkan faktor kedaluwarsa dan all unit discount. Goyal (1985) mengembangkan model dengan memperhatikan kelonggaran waktu pembayaran, sedangkan Silitonga \& Moses (2021) mengembangkan model EOQ yang memperhatikan all unit discount dan kendala kapasitas. Silitonga \& Iskandar (2021) mengembangkan model Limansyah (2011) dan Goyal (1985), yaitu menggabungkan perhatian pada masalah kedaluwarsa dan kelonggaran waktu pembayaran. Model inilah yang menjadi model acuan pada penelitian ini, untuk dikembangkan lebih lanjut dengan menambahkan perhatian pada faktor potongan harga all unit discount.

\section{METODOLOGI}

Penelitian dilakukan dengan langkah-langkah sebagai berikut. Penelitian dimulai dengan studi penelitian sebelumnya, perumusan masalah, penentuan tujuan dan manfaat penelitian. Setelah itu dilakukan studi literatur untuk mempelajari model-model terdahulu sebagai dasar pengembangan model. Penelitian dilanjutkan dengan pengembangan model.

Pengembangan model dilakukan dengan menggunakan Silitonga \& Iskandar (2021) sebagai model acuan yang telah memperhatikan kelonggaran waktu pembayaran dan kedaluwarsa. Model ini kemudian dikembangkan lebih lanjut dengan menambahkan faktor all unit discount yang diambil dari penelitian Limansyah (2011).

Model yang telah dikembangkan kemudian divalidasi. Validasi model dilakukan dengan cara verifikasi dan uji coba. Verifikasi model merupakan proses pemeriksaan setiap persamaan yang terdapat pada model, apakah satuan di sisi kiri persamaan sama dengan satuan di sisi kanan persamaan. Uji coba model dilakukan dengan mencoba memasukkan data-data sekunder yang didapat dari penelitian terdahulu, untuk melihat apakah model yang dikembangkan mampu menghasilkan komponen biaya dan biaya persediaan total. 
Tahap terakhir dalam penelitian ini adalah kesimpulan dan saran. Kesimpulan merupakan jawaban dari tujuan penelitian ini berdasarkan hasil pengembangan dan uji coba model. Saran ditujukan bagi penelitian lanjutan terkait kinerja model yang dikembangkan ini.

\section{HASIL DAN DISKUSI}

\section{A. Pengembangan Model}

Pengembangan model pada penelitian ini dapat menghasilkan dua kemungkinan skenario. Skenario pertama merupakan kondisi saat produk yang tidak rusak habis terjual sebelum batas kelonggaran waktu dilewati. Skenario kedua merupakan kondisi saat produk yang tidak rusak habis terjual setelah batas kelonggaran waktu dilewati sehingga akan dikenakan biaya denda oleh pemasok. Gambar 1 dan Gambar 2 adalah gambaran model dari masing-masing skenario.

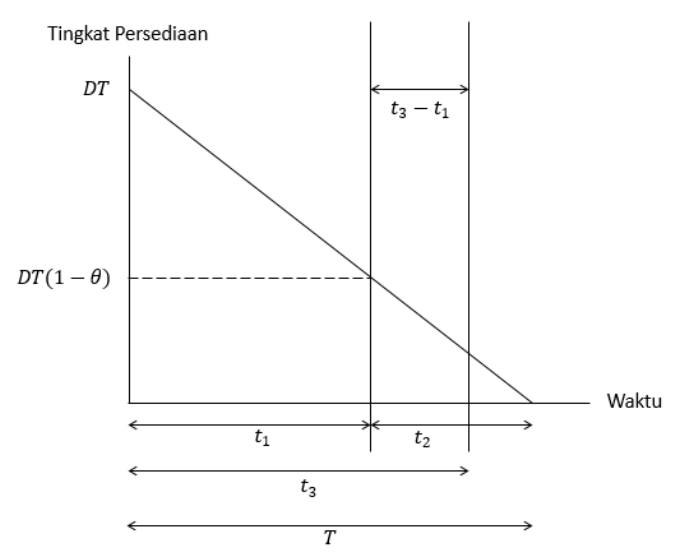

Gambar 1. Skenario 1

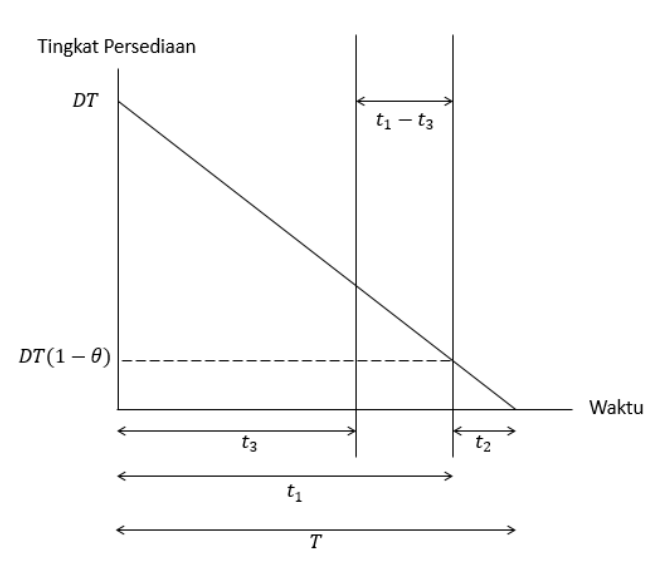

Gambar 2. Skenario 2

Untuk dapat memudahkan pemahaman dalam pengembangan model ini, berikut ini adalah penjelasan notasi-notasi yang digunakan dalam penelitian ini:

$\mathrm{D}=$ Permintaan dalam satu horizon perencanaan (unit)

$\mathrm{Q} \quad=$ Jumlah pesanan yang optimum per sekali pesan (unit)

$\mathrm{P}_{\mathrm{i}} \quad$ = Biaya pembelian per unit produk (Rp/unit)

$S \quad$ = Biaya pemesanan per sekali pesan (Rp/unit)

$h \quad=$ Fraksi biaya penyimpanan per unit per tahun (\%)

$\mathrm{C}_{\mathrm{p}} \quad=$ Biaya pembelian dalam satu horizon perencanaan (Rp)

$\mathrm{C}_{\mathrm{O}} \quad=$ Biaya pemesanan dalam satu horizon perencanaan $(\mathrm{Rp})$

$\mathrm{C}_{\mathrm{S}} \quad=$ Biaya penyimpanan dalam satu horizon perencanaan (Rp)

$\mathrm{C}_{\mathrm{SO}} \quad=$ Biaya kekurangan dalam satu horizon perencanaan $(\mathrm{Rp})$

$\mathrm{C}_{\mathrm{kd}} \quad=$ Biaya kerusakan dalam satu horizon perencanaan $(\mathrm{Rp})$

$\mathrm{C}_{\mathrm{c}} \quad=$ Biaya denda dalam satu horizon perencanaan $(\mathrm{Rp})$

$\mathrm{C}_{\mathrm{d}} \quad=$ Keuntungan bunga dalam satu horizon perencanaan $(\mathrm{Cd})$

$\mathrm{U} \quad=$ Biaya kekurangan per unit produk (Rp/unit)

$\mathrm{T}=$ Waktu pemesanan dari satu siklus ke siklus lainnya (tahun)

$\mathrm{t}_{1}=$ Periode hingga produk yang tidak rusak habis (tahun)

$\mathrm{t}_{2} \quad=$ Periode kekurangan produk (tahun)

$\mathrm{t}_{3} \quad=$ Lama kelonggaran waktu yang diberikan pemasok (tahun)

$\mathrm{I}_{\mathrm{d}} \quad=$ Persentase keuntungan yang bisa didapat per $\mathrm{Rp}$ yang diinvestasikan (\%)

$\mathrm{I}_{\mathrm{c}} \quad=$ Persentase denda yang dikenakan per Rp yang belum dibayarkan pada pemasok (Rp)

$\theta \quad=$ Fraksi produk tidak rusak $(\%)$

$(1-\theta)=$ Fraksi produk rusak $(\%)$

$\mathrm{R}_{\mathrm{j}} \quad=$ Batas maksimum jumlah barang yang dipesan untuk kelompok harga ke-j (unit)

$\mathrm{Z} \quad=$ Biaya persediaan total $(\mathrm{Rp})$ 

berikut:

Model yang dikembangkan ini berusaha meminimasi biaya persediaan total yang dinyatakan sebagai

Biaya persediaan total $=$ Biaya Beli + Biaya Pesan + Biaya Simpan + Biaya Kekurangan + Biaya Kerusakan + Biaya Denda - Bunga

Pengertian dan besarnya komponen jenis biaya yang mempengaruhi biaya persediaan total dalam persediaan model ini sebagai berikut:

1. Biaya Beli

Biaya ini merupakan biaya untuk membeli bahan baku/barang.

$P_{i}=\left\{\begin{array}{c}P_{0} \text { untuk } R_{0} \leq Q<R_{1} \\ P_{1} \text { untuk } R_{1} \leq Q<R_{2} \\ \vdots \\ P_{j} \text { untuk } R_{j} \leq Q<R_{j+1}\end{array}\right.$

di mana $P_{j}<P_{j+1}, j=0,1,2,3, \ldots$ untuk tiap unit barang. Sehingga biaya beli selama setahun adalah:

$$
\mathrm{C}_{\mathrm{p}}=\mathrm{P}_{\mathrm{i}} \mathrm{D}
$$

\section{Biaya Pesan}

Biaya pesan selama setahun adalah:

$$
\mathrm{C}_{\mathrm{O}}=\mathrm{S} \times \frac{1}{\mathrm{~T}}
$$

\section{Biaya Simpan}

Biaya simpan hanya ada pada periode $t_{2}$ dikarenakan periode $t_{2}$ tidak ada produk yang disimpan karena semua produk yang rusak akan langsung dibuang dikarenakan sudah tidak memiliki nilai jual. Biaya simpan selama setahun adalah:

$$
\mathrm{C}_{\mathrm{S}}=\mathrm{P}_{\mathrm{i}} \mathrm{h} \times \frac{(\mathrm{DT}+\mathrm{DT}(1-\theta))}{2} \times \mathrm{T} \theta \times \frac{1}{\mathrm{~T}}
$$

dimana $\mathrm{t}_{1}=\mathrm{T} \theta$

\section{Biaya Kekurangan}

Biaya kekurangan selama setahun adalah:

$$
\mathrm{C}_{\text {So }}=\mathrm{U} \times \frac{\mathrm{DT}(1-\theta)}{2} \times \mathrm{T}(1-\theta) \times \frac{1}{\mathrm{~T}}
$$

dimana $\mathrm{T}=\mathrm{t}_{1}+\mathrm{t}_{2}$

sehingga $\mathrm{t}_{2}=\mathrm{T}(1-\theta)$

\section{Biaya Kerusakan}

Biaya kerusakan selama setahun adalah:

$$
\mathrm{C}_{\mathrm{kd}}=\mathrm{DT}(1-\theta) \times \mathrm{P}_{\mathrm{i}} \times \frac{1}{\mathrm{~T}}
$$

\section{Biaya Denda}

Biaya ini muncul hanya dari skenario 2 dikarenakan produk yang tidak rusak baru habis terjual setelah melewati batas kelonggaran waktu pembayaran. Besar biaya denda selama setahun adalah:

$$
\mathrm{C}_{\mathrm{c}}=\mathrm{P}_{\mathrm{i}} \mathrm{I}_{\mathrm{c}} \times \frac{\left(\mathrm{DT}-\mathrm{Dt} \mathrm{t}_{3}+\mathrm{DT}(1-\theta)\right)}{2} \times\left(\mathrm{t}_{1}-\mathrm{t}_{3}\right) \times \frac{1}{\mathrm{~T}}
$$

\section{Keuntungan Bunga}

Keuntungan bunga dalam setahun adalah:

Skenario 1:

$$
C_{d}=\left(\frac{D t_{1}}{2} \times t_{1}+D t_{1} \times\left(t_{3}-t_{1}\right)\right) \times P_{i} I_{d} \times \frac{1}{T}
$$


Skenario 2:

$$
C_{d}=P_{i} I_{d} \times \frac{D t_{3}}{2} \times t_{3} \times \frac{1}{T}
$$

Penentuan biaya persediaan total yang minimum dan T optimal pada skenario 1 didapat jika $\frac{\delta Z}{\delta T}=0$ sehingga didapat:

$$
\mathrm{T}^{*}=\sqrt{\frac{2 \mathrm{~S}}{\mathrm{D} \theta \mathrm{P}_{\mathrm{i}} \mathrm{h}(2-\theta)+\mathrm{DU}(1-\theta)^{2}+\mathrm{D} \theta^{2} \mathrm{P}_{\mathrm{i}} \mathrm{I}_{\mathrm{d}}}}
$$

Hal yang sama dilakukan untuk mencari total biaya persediaan yang minimum dan T optimal pada skenario 2 didapat jika $\frac{\delta Z}{\delta T}=0$ sehingga didapat:

$$
\mathrm{T}^{*}=\sqrt{\frac{2 \mathrm{~S}+\mathrm{DP}_{\mathrm{i}} \mathrm{t}_{3}^{2}\left(\mathrm{I}_{\mathrm{c}}-\mathrm{I}_{\mathrm{d}}\right)}{\mathrm{D} \theta \mathrm{P}_{\mathrm{i}} \mathrm{h}(2-\theta)+\mathrm{DU}(1-\theta)^{2}+2 \mathrm{D} \theta \mathrm{P}_{\mathrm{i}} \mathrm{I}_{\mathrm{c}}+\mathrm{D} \theta^{2} \mathrm{P}_{\mathrm{i}} \mathrm{I}_{\mathrm{c}}}}
$$

Algoritma yang digunakan untuk mendapatkan solusi dapat dijabarkan sebagai berikut:

1. Hitung $T^{*}$ menggunakan persamaan (13) untuk semua tingkat harga sesuai skenario 1 .

2. Hitung $t_{1}$, cek apakah hasilnya sesuai dengan kondisi pada skenario $1\left(t_{1}<t_{3}\right)$. Jika ya, maka $T^{*}$ valid.

3. Jika hasil $t_{1}$ tidak sesuai dengan kondisi pada skenario 1 , hitung kembali $T^{*}$ untuk semua tingkat harga dengan persamaan (14) sesuai skenario 2 .

4. Hitung kembali $t_{1}$, apakah kondisi $t_{1}$ sesuai dengan kondisi pada skenario 2 . Jika ya, maka $T^{*}$ valid.

5. Hitung $Q$ pada setiap tingkat unit harga pembelian barang.

6. Bandingkan $Q$ dan $R$. Jika $Q$ berada dalam interval $R\left(R_{j} \leq Q<R_{j+1}\right)$, maka $Q$ valid dan lanjutkan ke langkah Bandingkan $Q$ dan $R$. Jika $Q$ berada dalam interval $R\left(R_{j} \leq Q<R_{j+1}\right)$, maka $Q$ valid dan lanjutkan ke langkah 8.

7. Jika $Q$ tidak valid, maka:

a. Untuk $Q$ yang lebih kecil dari interval $R$, gunakan $R_{j}$

b. Untuk $Q$ yang lebih besar dari interval $R$, gunakan $R_{j+1}$

8. Hitung seluruh $Z$ untuk setiap $Q$ yang valid.

9. Bandingkan hasil perhitungan $Z$.

10. Pilihlah $Q$ yang memberikan nilai $Z$ minimum.

\section{B. Uji Coba Model}

Setelah model berhasil dibangun, dilakukan verifikasi model dengan memeriksa konsistensi satuan di setiap persamaan, di mana didapatkan bahwa seluruh persamaan konsisten dalam satuan. Uji coba model kemudian dilakukan, dengan menggunakan data penelitian sebelumnya (Silitonga \& Iskandar, 2021), yang ditampilkan pada Tabel 1 dan Tabel 2. Besarnya bunga dan penalti menggunakan persentase yang berlaku saat ini ((Bank Central Asia 1, 2020) dan (Bank Central Asia 2, 2020)). Tabel 2 juga menunjukkan data numerik yang ditambahkan untuk mengatur penggolongan potongan harga secara all unit discount. Perhitungan $\mathrm{T}$ berdasarkan persamaan (13) menghasilkan $t_{1}$ yang lebih besar dari pada $t_{3}$, sehingga skenario yang dipilih adalah skenario 2. Perhitungan Q optimum berdasarkan skenario 2 untuk setiap harga ditampilkan pada Tabel 3.

Tabel 1

Data parameter model

\begin{tabular}{clc}
\hline No & \multicolumn{1}{c}{ Parameter } & Nilai \\
\hline 1 & Jumlah permintaan dalam satu tahun $(D)$ & 500 unit \\
2 & Fraksi biaya penyimpanan $(h)$ & 0,8 \\
3 & Fraksi produk dalam kondisi baik $(\theta)$ & 0,95 \\
4 & Jangka kelonggaran waktu pembayaran yang disepakati $\left(t_{3}\right)$ & 0,08 \\
5 & Persentase denda $\left(I_{c}\right)$ & 0,03 \\
6 & Persentase bunga yang didapat $\left(I_{d}\right)$ & 0,01 \\
\hline
\end{tabular}


Tabel 2

Data komponen biaya persediaan

\begin{tabular}{clcc}
\hline No & \multicolumn{1}{c}{ Komponen Biaya } & Nilai \\
\hline 1 & Harga beli produk dengan jumlah $\leq 160$ unit & $\mathrm{Rp}$ & 11.500 \\
2 & Harga beli produk dengan jumlah 161-180 unit & $\mathrm{Rp}$ & 11.000 \\
3 & Harga beli produk dengan jumlah 181-200 unit & $\mathrm{Rp}$ & 10.500 \\
4 & Harga beli produk dengan jumlah $>200$ unit & $\mathrm{Rp}$ & 10.000 \\
5 & Biaya pesan per sekali pesan & $\mathrm{Rp}$ & 150.000 \\
6 & Biaya kekurangan per unit produk & $\mathrm{Rp}$ & 50 \\
\hline
\end{tabular}

Tabel 3

Jumlah Q optimum setiap harga

\begin{tabular}{cc}
\hline Harga/Unit & $Q$ (unit) \\
\hline Rp 10.000,00 & 135 \\
Rp 10.500,00 & 132 \\
Rp 11.000,00 & 129 \\
Rp 11.500,00 & 126 \\
\hline
\end{tabular}

Berdasarkan langkah ke-6, hasil perhitungan Q optimum pada Tabel 3, perlu diperiksa berdasarkan batasan jumlah unit minimum untuk suatu harga, yang telah diatur pada Tabel 2. Berdasarkan hal tersebut, dilakukan perubahan $\mathrm{Q}$ optimum untuk setiap harga berdasarkan batasan jumlahnya, yang hasilnya ditampilkan pada Tabel 4.

Tabel 4

Jumlah Q optimal yang valid untuk setiap harga

\begin{tabular}{cc}
\hline Harga/Unit & $Q$ (unit) \\
\hline Rp 10.000,00 & 201 \\
$\operatorname{Rp~} 10.500,00$ & 181 \\
$\operatorname{Rp~} 11.000,00$ & 161 \\
$\operatorname{Rp~} 11.500,00$ & 126 \\
\hline
\end{tabular}

Tabel 5

Hasil pengolahan data

\begin{tabular}{|c|c|c|c|c|c|}
\hline \multirow{2}{*}{ No } & \multirow{2}{*}{ Hasil } & \multicolumn{4}{|c|}{ Harga Beli dari Pemasok } \\
\hline & & 10000 & 10500 & 11000 & 11500 \\
\hline 1 & Biaya persediaan total & $\operatorname{Rp} 6.862 .271$ & $\operatorname{Rp} 7.064 .956$ & $\mathrm{Rp} 7.256 .444$ & $\operatorname{Rp} 7.322 .240$ \\
\hline 2 & $\begin{array}{l}\text { Jumlah pemesanan } \\
\text { optimum }\end{array}$ & 201 unit & 181 unit & 161 unit & 126 unit \\
\hline 3 & $\begin{array}{l}\text { Jumlah produk yang } \\
\text { rusak }\end{array}$ & 38 unit & 35 unit & 32 unit & 26 unit \\
\hline 4 & $\begin{array}{l}\text { Jumlah produk yang } \\
\text { terkena denda }\end{array}$ & 94 unit & 82 unit & 71 unit & 54 unit \\
\hline 5 & Waktu antar pemesanan & 0,269 tahun & 0,263 tahun & 0,257 tahun & 0,251 tahun \\
\hline
\end{tabular}

Tabel 5 menunjukkan biaya persediaan total dan beberapa variabel yang didapat berdasarkan Q optimum di tabel 4. Bardasarkan langkah ke-10, didapatkan bahwa biaya persediaan total minimum sesuai Tabel 5 , terjadi pada harga beli Rp. 10.000,00. Pengamatan pada Tabel 5 juga menunjukkan jumlah produk yang rusak dan terkena denda untuk berbagai harga menunjukkan hasil yang konsisten, yaitu semakin kecil jumlah pemesanan optimum, semakin kecil pula jumlah produk yang rusak dan terkena denda, sesuai dengan proporsinya. 
Tabel 6

Komponen biaya persediaan harga beli produk Rp 10.000

\begin{tabular}{|c|c|c|c|}
\hline No & Komponen Biaya & Skenario 1 & Skenario 2 \\
\hline 1 & Validasi Q sesuai skenario $(\mathrm{Y} / \mathrm{N})$ & $\mathrm{N}$ & $\mathrm{Y}$ \\
\hline 2 & Biaya Beli & N/A & Rp 5.000.000 \\
\hline 3 & Biaya Pesan & $\mathrm{N} / \mathrm{A}$ & Rp $\quad 557.621$ \\
\hline 4 & Biaya Simpan & N/A & $\mathrm{Rp} \quad 908.200$ \\
\hline 5 & Biaya Kekurangan & $\mathrm{N} / \mathrm{A}$ & $\mathrm{Rp}$ \\
\hline 6 & Biaya Kerusakan & N/A & 380.000 \\
\hline 7 & Biaya Denda & $\mathrm{N} / \mathrm{A}$ & 16.641 \\
\hline \multirow[t]{2}{*}{8} & Keuntungan Bunga & N/A & $\mathrm{Rp} \quad 239$ \\
\hline & Total Biaya & N/A & Rp 6.862.271 \\
\hline
\end{tabular}

Tabel 6 menunjukkan hasil perhitungan akhir untuk semua komponen biaya serta biaya persediaan total untuk harga produk Rp.10.000,00, yang merupakan solusi optimum. Pada penelitian ini, skenario 1 tidak valid, sehingga komponen biaya dan biaya persediaan total yang valid adalah berdasarkan skenario 2. Hasil biaya pada skenario 1 dinyatakan not available (N/A), karena harga yang didapat tidak mungkin terjadi, seperti hasil persamaan (11) yang akan bernilai negatif (karena $t_{3}$ yang lebih kecil dari pada $t_{1}$ ).

Hasil yang didapat pada Tabel 6 menunjukkan bahwa model yang dikembangkan berhasil diuji coba menggunakan data sekunder dari penelitian sebelumnya. Algoritma yang dikembangkan juga dapat menentukan skenario yang valid dan menghasilkan seluruh komponen biaya serta biaya persediaan total. Meskipun demikian, model yang dikembangkan ini masih perlu untuk dianalisis lebih lanjut, terutama apakah suatu situasi nyata dapat menghasilkan skenario 1, maupun uji sensitivitas output akibat perubahan berbagai parameter model ini.

\section{KESIMPULAN}

Penelitian ini berhasil mengembangkan model deterministik dengan mempertimbangkan faktor kedaluwarsa produk, kelonggaran waktu pembayaran, dan potongan harga all unit discount. Verifikasi model telah dilakukan, juga uji coba model menggunakan data dari penelitian sebelumnya, yang menghasilkan $\mathrm{T}$ optimum dan Q optimum sesuai dengan skenario dua, dan seluruh komponen biaya dan biaya persediaan total. Jumlah produk yang rusak dan terkena denda pada berbagai harga produk menunjukkan hasil yang konsisten. Algoritma yang dikembangkan juga berhasil mengidentifikasi skenario yang valid. Penelitian lanjutan masih perlu dilakukan untuk melihat apakah skenario 1 mungkin terjadi, juga menguji lebih dalam terkait sensitivitas model ini, serta membandingkan hasil model ini dengan model sebelumnya.

\section{DAFTAR PUSTAKA}

Bahagia, S. N. (2006). Sistem Inventori. Bandung: ITB Press.

Bank Central Asia 1. (2020, April 25). Retrieved from https://www.bca.co.id/Individu/Sarana/Biaya-danLimit/Kartu-Kredit

Bank Central Asia 2. (2020, April 25). Retrieved from https://www.bca.co.id/Individu/sarana/kurs-dan-sukubunga/suku-bunga-simpanan

Goyal, S. (1985). Economic Order Quantity under Conditions of Permissible Delay in Payments. The Journal of the Operational Research Society, 36 (4), 335-338.

Limanjaya, B. \& Silitonga, R. Y. (2018). Development of Multi Item Probabilistic Inventory Model by Considering Perishable and Purchase Bonus Factor. Jurnal Telematika(Edisi Khusus IESC), 54-59.

Limansyah, T. (2011). Analisis Model Persediaan Barang EOQ dengan Mempertimbangkan Faktor Kadaluarsa dan Faktor All Unit Discount. Universitas Katolik Parahyangan. Bandung: Research ReportEngineering Science. 
Republik Indonesia. (1999). Undang-Undang No. 8 Tahun 1999 tentang Perlindungan Konsumen. Jakarta: Lembaran Negara Republik Indonesia Tahun 1999 No. 42, Tambahan Lembaran Negara Republik Indonesia no. 3821, Sekretariat Negara.

Silitonga, R. Y., \& Iskandar, C. (2021). Economic Order Quantity Model Considering Product Damage and Permissible Delay in Payment. International Conference on Industrial Engineering and Operations Management (pp. 1776-1782). IEOM Society International.

Silitonga, R. Y., \& Moses, J. (2021). Pengembangan Model Economic Order Quantity Multi Item dengan Mempertimbangkan All Unit Discount dan Kendala Kapasitas. Journal of Integrated System, 92-100.

Sunendar, J. (2019). Cara Mudah Memahami Laporan Keuangan. Pustaka Aura Semesta. 